\title{
Could there be an Atheistic Political Theology?
}

\author{
Mark T. Nelson
}

\begin{abstract}
Aвstract “Only a God can save us." So says Martin Heidegger in his pessimistic assessment of merely human philosophy's ability to change the world. The thought is not unique to Heidegger: another thinker who arrived at a similar conclusion was Heidegger's contemporary and sometime admirer, Carl Schmitt, in his idea of "political theology." I take up Schmitt's version of the idea and use it to examine the New Atheism, a relatively recent polemical critique of religion by an informal coalition of English-speaking scientists, philosophers, and writers. Taking Sam Harris's book The End of Faith (2005) as my test case, I ask whether the New Atheism can instructively be read as a Schmittian "political theology", not least because of its strongly anti-liberal implications for toleration of religious belief and practice. I close by posing the question of what sort of theory would deserve to be called an atheistic political theology and whether such a theory exists, or could exist.
\end{abstract}

Keywords Harris, Sam; Heidegger, Martin; liberalism; new atheists; political theology; Schmitt, Carl 


\section{INTRODUCTION}

"Only a God can save us" (Heidegger 1981, 57): thus Martin Heidegger bluntly assessed the prospects of philosophy-indeed of "all purely human endeavor"-to effect any change in the world. Heidegger was concerned specifically with liberalism's apparent helplessness in the face of the crisis of global technicity, but the idea can be generalized: we cannot "do" politics without some recourse to the divine, to some reality which transcends individual human beings.

The thought is of course not unique to Heidegger: another thinker who arrived at a similar conclusion was his sometime admirer, Carl Schmitt, in his idea of "political theology." Perhaps this should not be surprising, given the similarities and connections between the two men: they were almost exact contemporaries (Heidegger was born in 1889 and died in 1976; Schmitt was born in 1888 and died in 1985); both were raised as Roman Catholics but broke with the Church while young; both were deeply influenced by the writings of Nietzsche; both were critics of cosmopolitan, enlightenment liberalism; and, most infamously, both joined the Nazi Party in May 1933 and became leading intellectuals of the Nazi regime. The depth of Heidegger's commitment to National Socialism has been debated; not so for Schmitt: he was for a time the "crown jurist" for the Nazi regime, and ceased to be so only when he was (reportedly) ousted by jealous Nazi rivals in an internal dispute. ${ }^{1}$ And (apparently) he remained unapologetic about his involvement and his views to the end of his life. Both thinkers pursued academic careers in different German universities at the same time, and eventually became acquainted. According to Tracy B. Strong, "Around the time they both joined the Nazi Party, Schmitt initiated contact with Heidegger by sending him a copy of The Concept of the Political. Heidegger responded warmly and invited Schmitt to assist him in reconstituting the Law Faculty” (Strong 2007, xii). Given these similarities and connections, Strong suggests that "Schmitt comes close to being the Martin Heidegger of political theory" (Strong 2007, xii). ${ }^{2}$

1. As a referee for this journal has pointed out, such reports may be motivated and shaped by considerations of self-defense, both intellectual and moral, so they must be taken with more than a few grains of salt.

2. That said, there are some deep differences between the two thinkers. As an anonymous referee for this journal called my attention to, Heidegger criticized Schmitt's conception of political existence as "far too extrinsic" and "relativized" in his famous 1934-5 seminar on Hegel's Elements of the Philosophy of Right. For full references, as well as a balanced discussion, see Michael Marder (2014). 
In Schmitt's thought, the Heideggerian idea that only a God can save us shows up in his diagnosis that liberalism is inherently unstable and, even where stable, leads to "trivial" forms of life. His solution is a "political theology," in which all the attributes traditionally ascribed to God are transferred to the state. In the abstract, Schmitt's political theology may be considered a neutral, descriptive "sociology of juristic concepts:"

All significant concepts of the modern theory of the state are secularized theological concepts not only because of their historical development-in which they were transferred from theology to the theory of the state, whereby, for example the omnipotent God became the omnipotent lawgiver-but also because of their systematic and structure, the recognition of which is necessary for a sociological consideration of these concepts. (Schmitt 1985, 36)

However, it also constitutes the framework for a non-neutral, normative picture of political reality, analogous to a divine-command or voluntarist theory of ethics. Just as in a theological voluntarist theory of ethics there can be no external moral law to serve as a check on God's will, so in Schmitt's political theology morality cannot, in principle, serve as a check on the state and its sovereign acts. According to Schmitt, the state "is in the decisive case the ultimate authority" (Schmitt 2007, 20) and "Sovereign is he who decides on the exception" (Schmitt 1985, 5). Moreover, just as in Calvinist versions of divine voluntarism, where the sovereign God may (with no injustice) elect whomsoever he will to salvation or damnation, in Schmitt's political theology, "To the state as an essentially political entity belongs the jus belli, i.e. the real possibility of deciding in a concrete situation upon the enemy and the ability to fight him with the power emanating from the entity" (Schmitt 2007, 45). For Schmitt, this decisive identification of some person(s) as the enemy is the definitive political act; where there can be no enemy, ultimately there can be no politics. Only a god-like state can save, or sustain, the political sphere and keep it from degenerating into the unending, feckless discussion of liberal democracy.

The similarity and connection between Schmitt's views and Heidegger's has also been debated. On the one hand, there is the aforementioned letter, in which Heidegger expresses his pleasure over Schmitt's use of Heraclitus's Fragmentum 53: "War is the father of all things, the king of all things. Some he proves to be gods, others men; some he makes slaves, others free." Heidegger states that Schmitt's use of it appealed to him because "... you did not forget basileus [king], which gives definitive meaning to the whole maxim if one interprets it completely" (Heidegger 1933). Some read 
Heidegger's claim here as an acknowledgement that "War is King" and an affirmation of Schmitt's idea that violence is creative of identity: that is, as one political existentialist recognizing another as a kindred spirit. ${ }^{3}$

Nevertheless, others see Heidegger's remarks here as little more than mere conventional courtesy from one academic to another. Cambridge legal scholar Lars Vinx, for example, suggests:

Schmitt published a third edition of the Concept of the Political early in the Nazi period (which he later pretended didn't exist, since it contains a lot of open antisemitism), and it looks as though it must have been this version he sent to Heidegger, who, like Schmitt, was exploiting the Machtergreifung [seizure of power] for purposes of career advancement (and for obtaining more power in academia). Heidegger had been appointed as rector of one of Germany's most prestigious universities, and it may be that Schmitt simply wanted to network and curry favour with Heidegger. It seems that [Heidegger] brushed him off rather unceremoniously. (Vinx, pers.comm. June 3, 2021)

Regardless of the direction of influence, however, it cannot be disputed that Heidegger's and Schmitt's similarly grim assessments of politics grow out of the same-also grim-political milieu.

Unsurprisingly, Schmitt has long had admirers on the American right, including Leo Strauss and his followers, but he has also had admirers among the European left, including Walter Benjamin and Slavoj Zizek. ${ }^{4}$ Even so, few would be so bold as to praise Schmitt's approach unreservedly, and fewer still to claim that it is true. True or not, Schmitt's version of the idea that only a god can save us and, indeed, his definition of political theology may help us to interpret and classify contemporary philosophical trends. That will be the theme of this essay: I shall ask whether, given its unabashedly anti-liberal stance, the so-called "New Atheism" may be understood as a sort of Schmittian political theology. My answer will, despite some impressive parallels, be negative, but I shall argue that this sheds light on the New Atheism and Political Theology, and raises an interesting further question about whether this term can apply to any political thought that proclaims itself to be atheistic. ${ }^{5}$

3. For a related discussion, see Mensch (2017).

4. For a lucid discussion of Strauss's reception of Schmitt (and Heidegger), see Miner (2012); for an informative discussion of Schmitt's reception generally, see the references in Strong (2007) $\mathrm{x}$-xii.

5. I am indebted to an anonymous referee for this journal for clarification on this point. 


\section{Who ARe the New Atheists, And What Do They Think?}

The last two decades have witnessed the emergence of "the New Atheism," a hard-hitting polemical critique of religion by a loose coalition of English-speaking scientists, philosophers, and journalists. New Atheism has no formal membership, but some of its best-known exemplars are the philosopher/neuroscientist Sam Harris, the philosopher Daniel Dennett, the biologist Richard Dawkins and the late journalist Christopher Hitchens. The novelist Philip Pullman, in the His Dark Materials trilogy, has staked out the popular, literary wing of the movement, and Louise Antony's Philosophers without Gods (2007) contains some representative philosophical and autobiographical statements.

The main planks of the New Atheists' platform can be stated simply:

1. Religion is false.

2. Religion is bad.

3. Religion must be fought.

Their main targets are the Abrahamic religions, Christianity, Judaism and Islam-particularly Islam-but no religion is unscathed. Every religion from Mormonism to Micronesian Cargo Cults comes in for a beating, and so as not to show any favouritism, Christopher Hitchens criticizes even Buddhism, in a chapter entitled "There is no Eastern Solution." ${ }^{6}$ That said, the movement is not monolithic, and there are some interesting differences between these thinkers. In any case, I shall take Sam Harris as my prime example. Let us consider these claims in closer detail.

\section{i. Religion is False}

According to the New Atheists, when religions make substantive claims these tend to be false. For example, when religions make empirical or historical claims, the latter tend to be untrue-indeed, often absurdly so: "Some 46 percent of Americans take a literalist view of creation.... This means that 120 million of us place the big bang 2,500 years after the Babylonians and Sumerians learned to brew beer" (Harris 2005, 17). Likewise, when religions make metaphysical claims, these claims tend to be utterly unfounded, or at least incompatible with empirical naturalism. In particular, religious doctrines founded on scripture are unreliable, and this is hardly surprising, as "The Bible, it seems certain, was the work of sand-strewn men and women who thought the earth was flat and for whom a wheelbarrow would have been a breathtaking example of emerging technology" (Harris 
2005, 45). Moreover, Harris argues, scriptural interpretation is by its very nature insulated from rational self-criticism or moderation:

The doors leading out of scriptural literalism do not open from the inside. The moderation that we see among non-fundamentalists is not some sign that faith itself has evolved; it is, rather, the product of the many hammer blows of modernity that have exposed certain tenets of faith to doubt. (Harris 2005, 18-9)

It is important to Harris's argument that religions make substantive claims, and he resists woolly-minded attempts to reinterpret religions as expressing vague feelings or general outlooks. Harris insists that religious beliefs are genuine beliefs: that is, representations of the world that are made true or false by the world. Partly, this insistence is motivated by polemical reasons: the more beliefs a religion entails, the broader the target it presents for Harris's critical arrows. Partly, it is implicated by the second main criticism that Harris et al want to make: namely, that religion is bad.

\section{ii. Religion is Bad}

According to the New Atheists, religion is bad in a number of ways:

1. Religion makes us servile, keeping believers in a permanent state of infancy, slavery or abasement. Centuries ago, Shelley fulminated, "Religion! Who peoplest earth with demons, hell with men and heaven with slaves!" Hitchens concurs, asserting that "it manages to combine the maximum of solipsism with the maximum of servility" (Hitchens 2007, p. 4).

2. Particular religious teachings are opposed to human well-being (for example, the consequences of Roman Catholic teaching on contraception for AIDS and over-population).

3. Religions typically preach barbaric ethical standards and barbaric punishments for violations of these standards (for example, the codes regarding sex, diet, dress and slavery in Leviticus).

4. Religion is obscurantist, stifling free enquiry (for example, the fundamentalist rejection of evolutionary biology, attempts to mandate teaching of creation science in schools and the Bush administration's attempts to block stem-cell research) and censoring the arts (for example, Salman Rushdie and the Satanic Verses affair).

Most importantly:

5. Religion causes violence. According to Harris: 
That we are still dying on account of ancient myths is as bewildering as it is horrible, and our own attachment to these myths, whether moderate or extreme, has kept us silent in the face of developments that could ultimately destroy us. Indeed, religion is as much a living spring of violence today as it was at any time in the past. The recent conflicts in Palestine (Jews v. Muslims), the Balkans (Orthodox Serbians v. Catholic Croatians; Orthodox Serbians v Bosnian and Albanian Muslims), Northern Ireland (Protestants v. Catholics), Kashmir (Muslims v. Hindus), Sudan (Muslims v. Christians and animists), Nigeria (Muslims v. Christians), Ethiopia and Eritrea (Muslims v. Christians), Sri Lanka (Sinhalese Buddhists v. Tamil Hindus), Indonesia (Muslims v. Timorese Christians), and the Caucasus (Orthodox Russians v. Chechen Muslims; Muslim Azerbaijanis v. Catholic and Orthodox Armenians), are merely a few cases in point. In these places religion has been the explicit cause of literally millions of deaths in the last ten years. (Harris 2005, 25-6)

Moreover, it is not surprising that religion causes violence, because, the New Atheists allege:

a. Religions are intrinsically divisive, dividing humanity into Sheep and Goats, Us and Them, Elect and Reprobate.

b. Many religions, especially Christianity, are founded on a love of violent death and blood sacrifice.

c. Religions often justify claims on particular pieces of territory, making conflict inevitable.

d. Religions enshrine a moral monism, privileging one conception of the Good above all others. ${ }^{7}$ Such moral monism is bad enough on its own, but it becomes positively toxic when combined with a belief in the afterlife or an ideal of martyrdom, as argued by Richard Dawkins in the week after the attacks on the World Trade Center:

Could we get some otherwise normal humans and somehow persuade them that they are not going to die as a consequence of flying a plane smack into a skyscraper? If only! Nobody is that stupid, but how about this-it's a long shot, but it just might work. Given that they are certainly going to die, couldn't we

7. Compare Isaiah Berlin: "One belief, more than any other, is responsible for the slaughter of individuals on the altars of the great historical ideals-justice or progress or the happiness of future generations, or the sacred mission of emancipation of a nation or race or class, or even liberty itself, which demands the sacrifice of individuals for the freedom of society. This is the belief that somewhere, in the past or in the future, in divine revelation or in the mind of an individual thinker, in the pronouncements of history or science, or in the simple heart of an uncorrupted good man, there is a final solution" (Berlin 1958, 29). 
sucker them into believing that they are going to come to life again afterwards? Don't be daft! No, listen, it might work. Offer them a fast track to a Great Oasis in the Sky, cooled by everlasting fountains. Harps and wings wouldn't appeal to the sort of young men we need, so tell them there's a special martyr's reward of 72 virgin brides, guaranteed eager and exclusive. Would they fall for it? Yes, testosterone-sodden young men too unattractive to get a woman in this world might be desperate enough to go for 72 private virgins in the next. Do you know, I really think it might work. As luck would have it, we have just the thing to hand: a ready-made system of mind-control which has been honed over centuries, handed down through generations. Millions of people have been brought up in it. It is called religion.... Now all we need is to round up a few of these faith-heads and give them flying lessons. (Dawkins 2001)

Finally, one of the worst things about religion is that:

6. Religion requires faith. Religious beliefs typically derive from some religious authority, whether The Koran or the Pope or The Bible, but such authorities cannot be vindicated rationally, so they demand an attitude of obedience and faith, which Harris defines as "the license people give themselves to keep believing when reasons fail” (Harris 2005, 232-3).

As Harris puts it rather pointedly,

Tell a devout Christian that his wife is cheating on him, or that frozen yogurt can make a man invisible, and he is likely to require as much evidence as the next man. Tell him that the book he keeps by his bed was written by an invisible deity who will punish him with fire for eternity if he fails to accept its every incredible claim about the universe, and he seems to require no evidence whatever. (Harris 2005, 19)

This is Harris's main complaint against religion (hence the title of his book, The End of Faith), and it is his other reason for insisting that religious beliefs are beliefs, that is, attempts to represent the world that can be true or false. Since belief aims at the truth, individual beliefs must be based on reasons to think they are true, but faith is, on Harris's definition, belief in the absence of such reasons. This would not matter so much, except that, according to Harris, genuine beliefs are by their very nature linked to action: "A belief is a lever that, once pulled, moves almost everything else in a person's life" (Harris 2005, 12). Actions based on faith-that is, on no real evidence for their truth-will, especially when they concern matters of life and death, almost inevitably go disastrously wrong: 
Our past is not sacred for being past, and there is much that is behind us that we are struggling to keep behind us...: the divine right of kings, feudalism, the caste system, slavery, political executions, forced castration, vivisection, bear-baiting, honorable duels, chastity belts, trial by ordeal, child labor, human and animal sacrifice, the stoning of heretics, cannibalism, sodomy laws, taboos against contraception, human radiation experiments-the list is nearly endless, and if it were extended indefinitely, the proportion of abuses for which religion could be found directly responsible is likely to remain undiminished. In fact, almost every indignity just mentioned can be attributed to an insufficient taste for evidence, to an uncritical faith in one dogma or another. (Harris 2005, 25)

Faith is also what is wrong with atheistic totalitarian regimes such as Nazism and communism. Even though these systems were not religions, they resembled religions in requiring the same attitudes of faithful obedience from believers:

Even where such crimes have been secular, they have required the egregious credulity of entire societies to be brought off. Consider the millions of people who were killed by Stalin and Mao: although these tyrants paid lip service to rationality, communism was little more than a political religion. (Harris 2005, 79)

\section{iii. Religion Must be Fought}

Given these first two planks, the third plank in the New Atheist platform is hardly surprising: Religion must be fought. The New Atheists do not speak with one voice on this point-see the call for restraint in Shermer (2007) - but if there is one thing that sets the New Atheists apart from the Old Atheists (apart from mere chronology), it is their aggressive stance toward religion. For Harris and company, it is not enough that irreligion be defended as a valid choice; religion itself must be put to flight:

Our technological advances in the art of war have finally rendered our religious differences-and hence our religious beliefs-antithetical to our survival. We can no longer ignore the fact that billions of our neighbors believe in the metaphysics of martyrdom, or in the literal truth of the book of Revelation.... There is no doubt that these developments mark the terminal phase of our credulity. Words like "God" and "Allah" must go the way of "Apollo" and "Baal," or they will unmake our world. (Harris 2005, 13-4)

Similarly, philosopher Walter Sinnott-Armstrong writes of the need for atheists "to overcome Christianity in society and to pave the way for real 
progress" (in Antony 2007, 79), and Hitchens closes his book with this stirring call to arms:

We have first to transcend our prehistory, and escape the gnarled hands which reach out to drag us back to the catacombs and the reeking altars and the guilty pleasures of subjection and abjection. "Know yourself," said the Greeks, gently suggesting the consolations of philosophy. To clear the mind for this project, it has become necessary to know the enemy, and to prepare to fight it. (Hitchens 2007, 283)

\title{
III. Harris's Positive Program
}

Despite its critical posture, the New Atheism is not completely negative. New Atheists usually have something they want to put in the place of religion, but here, especially, the movement is not monolithic. Some, such as Hitchens, advocate a return to old-fashioned enlightenment humanism:

\begin{abstract}
Above all, we are in need of a renewed Enlightenment, which will base itself on the proposition that the proper study of mankind is man, and woman. This Enlightenment will not need to depend, like its predecessors, on the heroic breakthroughs of a few gifted and exceptionally courageous people. It is within the compass of the average person. The study of literature and poetry, both for its own sake and for the eternal ethical questions with which it deals, can now easily depose the scrutiny of sacred texts that have been found to be corrupted and confected. The pursuit of unfettered scientific inquiry, and the availability of new findings to masses of people by easy electronic means, will revolutionize our concepts of research and development. Very importantly, the divorce between the sexual life and fear, and the sexual life and disease, and the sexual life and tyranny, can now at last be attempted, on the sole condition that we banish all religions from the discourse. And all this and more is, for the first time in our history, within the reach if not the grasp of everyone. (Hitchens 2007, 283)
\end{abstract}

Harris, on the other hand, advocates a new direction, a distinctive combination of utilitarianism, neuroscience and Buddhist meditation. Some naturalists may fear that if God does not exist, then ethics is destroyed, but Harris is not one of them:

A rational approach to ethics becomes possible once we realize that questions of right and wrong are really questions about the happiness and suffering of 
sentient creatures. If we are in a position to affect the happiness or suffering of others, we have ethical responsibilities toward them. (Harris 2005, 170-1)

Harris denies that this boils down to utilitarianism (see Harris 2005, 272), but he never gives his reasons for this denial, and the similarity is near enough to be striking. In any case, once we see that ethics is all about the happiness and suffering of other creatures, we can begin to see it as a "Science of Good and Evil" (as Chapter 6 of The End of Faith is entitled). Happiness and suffering are conscious states of conscious beings, so science in general and neuroscience in particular-Harris was, at that time, a $\mathrm{PhD}$ candidate in neuroscience-can help us to understand these states and the actions that flow from them. But neuroscience can only take us so far: it studies the sort of beings we are and the sorts of experiences we have, but, according to Harris, these experiences are radically unsatisfactory.

The basic (and I think uncontestable fact) is that almost every human being experiences the duality of subject and object in some measure, and most of us feel it powerfully nearly every moment of our lives. It is scarcely an exaggeration to say that the feeling that we call "I" is one of the most pervasive and salient features of human life: and its effects upon the world, as six billion "selves" pursue diverse and often incompatible ends, rival those that can be ascribed to almost any other phenomenon in nature. Clearly, there is nothing optimal-or even necessarily viable-about our present form of subjectivity. Almost every problem we have can be ascribed to the fact that human beings are utterly beguiled by their feelings of separateness. It would seem that a spirituality that undermined such dualism, through the mere contemplation of consciousness, could not help but improve our situation. (Harris 2005, 214)

Fortunately, claims Harris, a rich tradition of research into the transformation of consciousness already exists in the meditative practices and writings of the East. Harris quotes, for example, from a treatise by the eight-century Tantric Buddhist, Padmasambhava, about the clarity and emptiness of pure awareness, and then observes that "one could live an eon as a Christian, a Muslim or a Jew and never encounter any teachings like this about the nature of consciousness" (Harris 2005, 216). He acknowledges that "its meaning may not be perfectly clear to all readers", but he insists it is "a rigorously empirical document, not a statement of metaphysics" (Harris 2005, 217).

Has Harris lost his atheistic nerve here, and swerved back into religion? Most certainly not! 
While Buddhism has... been a source of ignorance and occasional violence, it is not a religion of faith, or a religion at all, in the Western sense. There are millions of Buddhists who do not seem to know this, and they can be found in temples throughout Southeast Asia, and even the West, praying to Buddha as though he were a numinous incarnation of Santa Claus. This distortion of the tradition notwithstanding, it remains true that the esoteric teachings of Buddhism offer the most complete methodology we have for discovering the intrinsic freedom of consciousness, unencumbered by any dogma. (Harris 2005, 293-4)

\section{HARRIS IS NOT A LIBERAL}

Having characterized the main planks of the New Atheist platform, we may now consider further how the New Atheism of Harris and Hitchens differs from the Old Atheism of Lucretius, Hume, and Bertrand Russell. Up to a point, there is no clear answer to this. As I have stressed throughout, the New Atheism is not a monolithic entity, and some of the New Atheists see themselves as continuous with that older, heterogeneous tradition that includes freethinkers of all stripes: agnostics, Spinozists and Voltairean deists, as well as atheists. ${ }^{8}$

If there is a difference between the New and the Old Atheists, however, I suggest it is the New Atheists' especially aggressive stance toward religion. To a certain extent, even this is a difference of degree and not of kind: some of the New Atheists are making the same old criticisms, just more loudly than before. But the stance of some New Atheists is more aggressive than that. The Old Atheism defended the notion that unbelief was an acceptable option, and that unbelievers should thus be left alone. ${ }^{9}$ The New Atheism, however, does not want merely to be left alone by the religious; it wants to vanquish religion, intellectually and practically.

The desire to take the battle to the believers is especially clear in Harris. He argues, for example, that:

1. Belief is not a private matter: "It is time we recognized that belief is not a private matter; it has never been merely private. In fact, beliefs are scarcely more private than actions are, for every belief is a fount of action in potentia" (Harris 2005, 44).

2. "Certain beliefs are intrinsically dangerous" (44), because as Harris has argued, "As a man believes, so he will act."

8. This is most clearly true of Hitchens. See his Chapters 18 and 19, "The Resistance of the Rational" and "The Need for a New Enlightenment."

9. For a despairing cri de coeur about this, see Hitchens $(2007,13)$. 
For Harris, it is a short step from (1) and (2) to:

3. "Some propositions are so dangerous that it may even be ethical to kill people for believing them" (Harris 2005, 52-3). And the political upshot of (3) includes:

4. Recent military actions by the US and their western allies in the War on Terror are justified: "Our subsequent actions in Afghanistan and elsewhere are justified because of what will happen to more innocent people if members of $\mathrm{Al}$ Qaeda are allowed to go on living by the light of their peculiar beliefs" (Harris 2005, 246). This includes some (but not all) of the actions that lead to the accidental killing of innocent civilians. ${ }^{10}$

5. There is ethical parity between military actions that cause "collateral damage" and the use of torture to extract vital information from, for example, Islamic extremists.

From (4) and (5), we get:

6. It is ethically permissible to use torture in certain circumstances: "I believe that the account offered above is basically sound, I believe that I have successfully argued for the use of torture in any circumstances in which we would be willing to cause collateral damage" (Harris 2005, 198).

Going beyond (4)-(6), Harris argues that:

7. Pacifism is not just not-obligatory, it is "flagrantly immoral": "While it can seem noble enough when the stakes are low, pacifism is ultimately nothing more than a willingness to die, and to let others die, at the pleasure of the world's thugs" (Harris 2005, 199).

While the Old Atheism was often linked to freethinking and Enlightenment liberalism, the New Atheism (at least in the work of Harris) seems to have broken this link decisively. In case this is not already obvious, let us consider the matter more closely. It is a commonplace in contemporary political philosophy that there is no simple definition of political liberalism, but the position is generally thought to involve all or most of the following cluster of ideas or commitments:

1. Advocacy of a sharp public/private division, with religious belief and practice on the protected private side of the divide. ${ }^{11}$

10. For some qualifications, see Harris $(2005,286-7)$.

11. According to one leading liberal, "Modern liberalism is concerned not only to protect the private sphere of social life, but also to carve out a realm within the private sphere where individuals can have privacy" (Kymlicka 1999, 258). 
2. Conceptual separation of the Right and the Good, with the Right identified as prior to the Good. ${ }^{12}$

3. A commitment to equal respect for persons, entailing neutrality between competing conceptions of the Good, typically motivated by skepticism or pluralism about these various conceptions. ${ }^{13}$

4. A recognition of the primacy of robust individual rights, including rights to life, liberty and security of person, rights against torture and arbitrary arrest or detention, rights against arbitrary interference with one's privacy, family, home or correspondence, the right to freedom of thought, conscience and religion, and the right to manifest one's religion or belief in teaching, practice, worship and observance. ${ }^{14}$

5. Given the above, official policies of toleration toward all creeds and religions.

6. Advocacy of the democratic polity and its extension.

And yet, if this is liberalism, then Sam Harris is no liberal, as he forthrightly rejects all of these points: ${ }^{15}$

12. This is most evident in the work of Rawls's middle period: "This priority of the right over the good in justice as fairness turns out to be a central feature of the conception" (Rawls 1971, 31-2).

13. A representative statement of this position can be found in Ronald Dworkin, who argues that liberalism takes as its "constitutive political morality" the conception of equality according to which "political decisions must be, so far as is possible, independent of any particular conception of the good life, or of what gives value to life. Since the citizens of a society differ in their conceptions, the government does not treat them as equals if it prefers one conception to another...." (Dworkin 1984, 64).

14. See, for example, United Nations Universal Declaration of Human Rights, 1948, esp. articles 3, 5, 9, 12 and 18 .

15. It may be observed that this way of defining Liberalism makes the idea of "authoritarian liberalism" a contradiction in terms. And this might be thought unfortunate because, as an anonymous referee for this journal has pointed out, such positions, paradoxical as they may sound, are not unknown in political reality, and they might afford us an illuminating way to classify New Atheists such as Harris. Whether or not it is truly paradoxical depends, of course, on how we define our terms. According to the "cluster definition" given above, the core idea of what I am calling "Liberalism" is moral: something like "equal rights" or "equal respect for persons." According to the standard definition of "authoritarian liberalism", however, the core idea of that position is economic. Michael A. Wilkinson, for instance, characterizes authoritarian liberalism as occurring when "politically authoritarian forms of governing promote programmes (and defend material constellations) of economic liberalism" such as capital accumulation, marketization, economic rationality, and fiscal austerity (Wilkinson 2019, 317). Interestingly, one of the better-known twentieth-century proponents of this sort of position, according to Wilkinson, was none other than Carl Schmitt. See his "Strong State, Sound Economy," reprinted in R. Cristi, Carl Schmitt and Authoritarian Liberalism: Strong 
- He rejects, for example, the extension of the democratic polity in the Muslim world: "...were democracy to suddenly come to these countries, it would be little more than a gangplank to theocracy" (Harris 2005, 132).

- He rejects, as we have already seen, the idea that belief is a private matter (Harris 2005, 44).

- He implicitly rejects the priority of the right over the good, by making the pursuit of happiness and avoidance of misery the basis of his "Science of Good and Evil."

- He rejects neutrality about competing conceptions of the good: religious conceptions of the good are false and bad (at best puritanical about physical pleasure, but more often violent and life-denying). ${ }^{16}$

- He rejects (or severely qualifies) the liberal rights enumerated above, at least in the context of the War on Terror.

- He rejects official policies of toleration towards all creeds and religions. As I have already suggested, this is the point on which Harris's New Atheism is most at odds with traditional liberalism and the Old Atheism that went hand and hand with it. The Old Atheist said, in effect, "God probably doesn't exist, but proof is difficult to have on such matters, so we must respect each person's right to believe as they see fit." But Harris is having none of that, and he heaps scorn on this sort of liberal tolerance. Having observed that "criticizing a person's faith is currently taboo in every corner of our culture" (Harris, 2005, 13), he argues that "...the very ideal of religious tolerance-born of the notion that every human being should be free to belief whatever he wants about God-is one of the principal forces driving us toward the abyss" (Harris 2005, 15).

State, Free Economy, Cardiff: University of Wales Press, 1998). While it would be a delicious irony if Harris turned out be a Schmittian in this further sense, I doubt that he can plausibly be construed as an authoritarian liberal, for the simple reason that he presents no theory of political economy at all, let alone one committed to market principles. It may seem a glaring omission for a book of this size and sort, but the index for Harris's The End of Faith contains no entries for "free market", "capitalism", "laissez-faire", "liberalism", "neo-liberalism," or even "economics."

16. See Harris's Chapter 5, "West of Eden," for his account of American public policy as driven by puritanical Christianity: "When one looks at our drug laws-indeed, at our vice laws altogether-the only organizing principle that appears to make sense of them is that anything which might radically eclipse prayer or procreative sexuality as a source of pleasure has been outlawed" (Harris 2005, 160). 


\section{HARRIS CAN'T BE MADE INTO A LIBERAL, EITHER}

In all these ways, but most especially in his rejection of religious toleration and his advocacy of force against persons with certain religious beliefs, Harris appears to have abandoned traditional liberalism. It might be replied, however, that this appearance is only superficial, and that Harris's views, anti-liberal as they seem, can be defended in liberal terms. After all, it is not as if Liberals are forever barred from using force in times of emergency. Let us therefore consider the usual reasons to which liberals appeal in order to justify the use of force against persons.

\section{i. Punishment}

One clear example of justified force according to Liberalism is judicial punishment. Liberals may disagree over consequentialist versus retributive rationales for the institution of punishment, but they typically agree on what punishment is and agree that force may be used in carrying it out. Would Harris appeal to the liberal conception of punishment to defend his recommendation of force against, for example, Al Qaeda? I doubt it. At least, he rejects the idea that the War on Terror is justified on retributive grounds:

We do not have to bring the membership of Al Qaeda "to justice" merely because off what happened on Sept. 11, 2001. The thousands of men, women and children who disappeared in the rubble of the World Trade Center are beyond our help-and successful acts of retribution, however satisfying they may be to some people, will not change this fact. (Harris 2005, 246)

More importantly, I suggest that he cannot, and to see why not we need only consult the standard liberal definition of punishment. For an action to count as punishment, it must satisfy all of the following conditions:

i. It must involve pain or other consequences normally considered unpleasant

ii. It must be for an offense against a legal rule.

iii. It must be of an actual or supposed offender for his offense.

iv. It must be intentionally administered by human beings other than the offender.

v. It must be imposed and administered by an authority constituted by a legal system against which the offense is committed (Hart 1963, 4-5). But as soon as these conditions are stated, we can see that for a use of force against a religious believer, simply because he believes certain things, to count as punishment, religious belief itself would have to count as an offense against a legal rule, and no liberal could accept that. 


\section{ii. Quarantine}

Quarantine is another application of force that many of us in principle accept. We take ourselves to be justified in coercing or otherwise severely curtailing the rights of those who would, if allowed to remain at large, pose a serious threat to public health through infectious disease. Harris himself invokes the comparison:

Given the link between belief and action, it is clear that we can no more tolerate a diversity of religious beliefs than a diversity of beliefs about epidemiology and basic hygiene. There are still a number of cultures in which the germ theory of disease has yet to put in an appearance, where people still suffer from a debilitating ignorance on most matters relevant to their physical health. Do we "tolerate" these beliefs? Not if they put our own health in jeopardy. (Harris 2005, 46)

Indeed, he goes so far as to say that "it is not difficult to imagine a society whose beliefs relative to epidemiology could systematically impose unacceptable risks on the rest of us. There is no doubt that we would ultimately quarantine, invade, or otherwise subjugate such a society" (Harris 2005, 243).

Could Sam Harris appeal to this line of reasoning to show that he is a liberal? I don't think so. For one thing, it is surprisingly hard to justify on liberal grounds the rights-violations that extensive quarantine restrictions typically involve. ${ }^{17}$ More importantly, this line of reasoning can be extended to the subjugation or killing of religious believers (for holding religious beliefs) only if we accept that religious belief is itself a kind of disease.

Harris, as the quotation above illustrates, does think of religious belief as similar to disease, and in this he is not alone. In a lament over the radical Judaism that he sees stretching from the Maccabees to Meir Kahane, Christopher Hitchens likens it to "a poisonous branch that should have been snapped off long ago, or allowed to die out, before it could infect any healthy growth with its junk DNA" (Hitchens 2007, 275). But this is simply to abandon, in stark fashion, liberalism's neutrality about competing conceptions of the good, and to advocate a specifically non-religious conception instead.

17. Not surprisingly, perhaps, many liberals try to justify quarantine restrictions as a species of punishment, which requires seeing infected persons' failure to quarantine themselves as a crime. See Corrado (1996) and Selgelid (2009). 


\section{iii. Commission}

The same goes for appeals to "commission"-that is, the forceful incarceration of the mentally ill. As with quarantine, it takes some work to justify even this on liberal grounds, but if we wish to extend the justification so as to apply to religious beliefs per se, we have to view these religious beliefs themselves as a case of mental illness. This idea is, of course, not wholly alien to the New Atheists. As the title of Richard Dawkins's book suggests, he regards belief in God as a delusion, and Christopher Hitchens views it as a kind of mental illness born of sexual repression..$^{18}$ Harris's take on it is more nuanced:

While religious people are not generally mad, their core beliefs absolutely are. This is not surprising, since most religions have merely canonised a few products of ancient ignorance and derangement and passed them down to us as though they were primordial truths. This leaves billions of us believing what no sane person could believe on his own. In fact, it is difficult to imagine a set of beliefs more suggestive of mental illness than those that lie at the heart of many of our religious traditions. (Harris 2005, 72)

Whether or not this is correct, it again appears to abandon liberal neutrality about conceptions of the good. The liberal cannot consistently maintain that belief in God is both madness and one acceptable life choice among many.

\section{iv. Self-defense}

Probably the best way to justify Harris's bellicose stance toward religion on liberal grounds would be to view it as self-defense-of the sort that motivates contemporary versions of just war theory. According to traditional versions of just war theory, the only legitimate basis for jus ad bellum is self-defense, and even when contemporary just war theorists extend the bases, these extensions are supposedly justified on grounds of defense of vulnerable third parties. ${ }^{19}$ Even on the extended versions of the just war theory such as Michael Walzer's, "Nothing but aggression can justify a war" (Walzer 2006, 62).

There is no doubt that one of Harris's main concerns is the violence perpetrated by religious believers in the name of religion. He spends page after page cataloguing the various atrocities (and their supposed scriptural

18. See Hitchens $(2007,53)$.

19. Michael Walzer (2006) is not a perfect example of a liberal, but see his account of the Legalist Paradigm and its modifications in Chapters 4-6 of fust and Unjust Wars. 
warrants) in, for want of a better expression, "finger-licking" detail. Moreover, his call to arms against religion is sometimes justified explicitly in terms of self-defense against religious violence:

There is, in fact, no talking to some people. If they cannot be captured, and they often cannot, otherwise tolerant people may be justified in killing them in self-defense. This is what the United States attempted in Afghanistan, and it is what we and other Western powers are bound to attempt, at an even greater cost to ourselves and to innocents abroad, elsewhere in the Muslim world. We will continue to spill blood in what is, at bottom, a war of ideas. (Harris 2005, 53)

But notice: according to standard, liberal versions of the just war theory, only actual aggression justifies the use of force; mere ideas do not. Mere ideas are supposed to reside safely on the private side of the public/private divide beloved of liberals, and justify forceful intervention only when they spill over into action. We have already seen that Harris rejects the public/ private distinction on this point, but that merely serves to underscore his rejection of liberalism.

I conclude that Harris is not a liberal and cannot be made into a liberal, at least if we take seriously his recommendations about the use of force against religious believers and religious beliefs per se, which, I have argued, are the main differences between his New Atheism and the liberal atheism of earlier generations. ${ }^{20}$ Suffice it to say, it is a far cry from the Jeffersonian liberalism according to which "... it does me no injury for my neighbor to say there are twenty gods or no God. It neither picks my pocket nor breaks my leg" (Jefferson 1782, 159).

\section{Harris as Political Theologian?}

So, if Harris is not a liberal, what is he? Perhaps we should consider the hypothesis that he is a Schmittian political theologian. ${ }^{21}$ What would be the point of such hypothesizing? In the first instance, it is diagnostic or interpretive: it may help us understand what Harris says and why he says it, and to situate Harris's New Atheism on the wider political map. But the exercise may also have a critical function: if we want to criticize (or

20. To be fair, I note again that Hitchens is more nearly an old-fashioned liberal who "would not prohibit religion even if he thought he could." See Hitchens (2007, 12-3).

21. Simon Critchley does not mention Harris, but he sees a "crypto-Schmittian" agenda behind the Bush administration's War on Terror and its foreign and domestic policy generally. See Critchley (2006). 
defend) Harris, then, if the analogy is an apt one, whatever we say about Carl Schmitt we may also say about Harris. And there are some striking philosophical resemblances:

1. In Schmitt, as in Harris, we find an insistence on truth and the connection between belief and action.

2. In Schmitt, as in Harris, we find a rejection of the value neutrality that is characteristic of liberalism.

3. In Harris, as in Schmitt, we find a rejection of the relativism and pragmatism on which some liberals (for example, Rorty) would found their liberalism. ${ }^{22}$

4. In both Harris and Schmitt, we find a rejection of the same core liberal commitments to toleration, universal human rights, universal democracy and "perpetual discussion." ${ }^{23}$

5. Allied to (4), in both Harris and Schmitt we find the practical worry that the liberal state's preoccupation with toleration and the extension of democracy opens the door to its own destruction.

6. Given (2), (4) and (5), and especially given Harris's repudiation of inviolable and universal human rights in the War on Terror, we may even glimpse in Harris, as we see clearly in Schmitt, the analogy of a transfer to secular political entities of powers and properties previously associated only with a sovereign God.

7. Finally, we even find in Harris an awareness of something like Schmitt's distinction between friend and enemy, with the corresponding awareness that our enemy is someone we may have to kill:

It may seem strange to encounter phrases like "our enemies", uttered without apparent self-consciousness, and it is strange for me to write them. But there is no doubt that enemies are what we have.... The liberal fallacy that I will attempt to unravel in the present section is the notion that we made these enemies and that we are therefore their "moral equivalent." We are not. An analysis of their religious ideology reveals that we are confronted by people

22. See, for example, Harris $(2005,279-83)$, for that author's rejection of Davidsonian and Rortian relativism.

23. See, for example, Harris's remark above that "there is no talking to some people," and Schmitt's acerbic characterization of a liberal as someone who, if asked "Christ or Barabbas?" responds "with a proposal to adjourn or appoint a committee of investigation" (Schmitt 1985, 62) (quoted in Tracy B. Strong, "Foreword” to Schmitt 1996, xvi). 
who would have put us to the sword, had they had the power, long before the World Bank, the International Monetary Fund, and the World Trade Organization were even a gleam in the eye of the first rapacious globalizer. (Harris $2005,265)^{24}$

\section{The Lesson of the Naked Mole Rat}

Having adduced these similarities, I must admit that I am not persuaded that, deep down, Sam Harris is a true Schmittian, or that his version of the New Atheism is Schmittian "Political Theology." It pains me to admit this, because initially I thought it would be easy to make the case, and I was amused by the anticipated irony of being able to pin the "theologian" label on such a ferocious critic of religion. There are parallels between the two views, as I have noted, and they go deeper than one might suppose, but I do not think they go deep enough.

The point is not merely that they emerge from utterly different cultural milieus (a Roman Catholic German jurist from the Weimar Republic and a twenty-first century Stanford-educated philosopher turned neuroscientist) with utterly different motivations. It is that, even if both are anti-liberal, they are anti-liberal in very different ways. Harris's anti-liberalism appears to be a temporary, morally motivated policy, intended as a response to the crisis of religious fundamentalism, especially radical Islam. (He says he started his writing his book on September 12th, 2001.) On the other hand, while Schmitt's anti-liberalism was, in its own way, a response to a perceived crisis, and is intended to have practical policy implications, it is also (and primarily) a political philosophy. This becomes apparent when we notice what is lacking in Harris that is present in Schmitt. In Harris, we lack:

1. a sociology of juristic concepts, along with Schmitt's allied historical account of "epochs;" 5

2. a concept of the sovereign act;

3. a decisionist theory of law;

4. a theory of "the political" as an autonomous sphere;

5. a doctrine of the state;

6. a comprehensive political philosophy of any sort.

This last point is hardly surprising, nor is it meant to be insulting: Harris writes as a polemically motivated neuroscientist and ethicist, never claiming 
to be political philosopher. ${ }^{26}$ But, if Harris is not a Schmittian political theorist, what is he? Perhaps we should reconsider the possibility that Harris is, like some of his New Atheist fellow travelers, really a liberal at heart, and that his illiberal policy recommendations are either hyperbole or even a manifestation of the tensions and contradictions inherent in that position.

Though we cannot completely rule out this interpretation, I do not think it does justice to Harris. A more charitable and extendable interpretation of Harris is to read him as a utilitarian moralist of a slightly odd, crypto-Buddhist stripe. That is, even if he sometimes walks and talks like Carl Schmitt, he is really the heir of Jeremy Bentham and Peter Singer (and not of Kant or Rawls). This would make sense of his aspirations to a Science of Good and Evil, based on the pursuit of happiness and the avoidance of misery. It would also make sense of his understanding of happiness and misery as conscious states that can be technically enhanced and manipulated. It would further make sense of his affinity for secular, technological, capitalist society (about which Schmitt-like Heidegger-had such serious reservations). And it would make perfect sense of the anti-liberal character of his policy recommendations. Ever since Bentham's mockery of natural rights as "simple nonsense" and imprescriptible rights as "nonsense on stilts," the philosophy of the Greatest Happiness for the Greatest Number has never completely shaken off its reputation as being a little too ready to squish the individual in the pursuit of maximal utility. ${ }^{27}$ It would even make sense of the lack of a developed philosophy of "the political" noted above. After all, utilitarianism is the ethical universalism par excellence, according to which everything is ultimately a matter of ethics and there simply is no conceptual space for an autonomous political sphere or autonomous "existential acts."

For all these reasons and more, I reluctantly conclude that Harris's version of the New Atheism is not plausibly construed as Schmittian political theology. Does this mean that our reflections on the New Atheism have been in vain? I suggest that it does not, because even if the examples of the New Atheism that we have examined so far do not count as political theology, it is still worth asking whether there could be an atheistic political theology. ${ }^{28}$ In case this seems purely fanciful, let us take a brief detour through the zoology of Heterocephalus glaber.

26. Harris's argument seems not to be about the state at all. Harris thinks that we need to fight religion, but it is not clear that "we" means anything other than "right-thinking people" or humanity in general.

27. See the "Critique of the Doctrine of Natural, Inalienable Rights" in Bentham (1843).

28. Moreover, Schmitt himself appeared to believe that such a view was possible. As another commentator points out, "It must be emphasized that for Schmitt atheism is far from a merely 
In the mid-1970s, entomologist Richard Alexander was lecturing at Northern Arizona University on "eusociality," the hive social structure that is commonly observed in insects. (Eusociality involves, among other things, a large number of organisms living in a colony with a queen who is the only female who reproduces and who is served by a small number of males. The rest of the colony, of both sexes, have suppressed reproductivity and have a specialized division of labor into either workers or soldiers. $)^{29}$ Alexander remarked off-hand that no known examples of eusociality among mammals existed, but conjectured that, if a eusocial mammal were to exist, it would most likely be a small, fast-breeding rodent that lived underground in a protected environment without having to leave its colony for food. A biologist in the audience told Alexander that an east African species, Heterocephalus glaber, better known as the Naked Mole Rat, might fit the bill-though it was not known whether the Naked Mole Rat was eusocial or not. Alexander was then put in touch with zoologist Jennifer Jarvis, who was already investigating the Naked Mole Rat, and eventually Jarvis discovered that the Naked Mole Rat was indeed eusocial. That is, Alexander first described what a hive mammal would have to be like, and only later was a creature fitting that description discovered to exist.

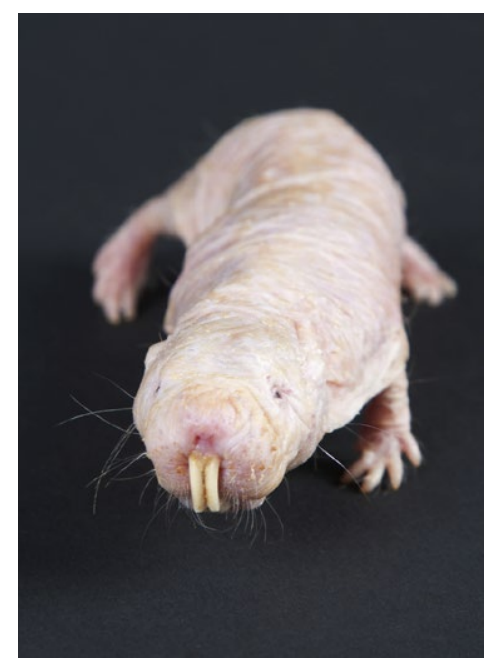

(Photo: CCO open access, Smithsonian's National Zoo \& Conservation Biology Institute: https:// nationalzoo.si.edu/openaccess/search?edan_ local=1\&edan_q=naked $\% 20$ mole-rat $\&$, accessed 11 November 2021)

metaphysical creed. Atheism is a political doctrine precisely in the way that Schmitt outlines in The Concept of the Political, i.e., that atheism had in the nineteenth century and to an even greater extent, in the twentieth century, become so intense that it grouped men according to friend and enemy." See Christopher McKoy, "The Mirror of Liberalism: An Anti-Liberal Formalist Analysis of Carl Schmitt's Political Theology" (unpublished manuscript).

29. See, for example, Sherman et al (1991). 
Returning to our discussion of New Atheism and political theology, I suggest that it is indeed worth asking whether there could be an atheistic Schmittian political theology, and what it would have to be like. I do not know where it would reside, but I suggest that, if there were to be such a thing, it would be:

1. an anti-liberal view, that had

2. an autonomous conception of "the Political", and

3. a decisionist view of law, and

4. a view of the state defined in terms of a friend/enemy distinction such that

5. religions in general were recognized as the enemy, and treated accordingly.

With the lesson of the Naked Mole Rat in mind, I close by posing these questions to the experts in political zoology among us: Could such a creature exist? Does it?

\section{ACKNOWLEDgEMENTS}

The writing of this essay was supported by the Provost's Office of Westmont College. A distant ancestor of it was presented to the Conference on Political Theology, at the Sciences-Po, Paris in August 2008. I am grateful for this support and to my discussants on that and other occasions for helpful comments, criticisms and references, especially: Gordon Finlayson, Christopher McKoy, Robert Miner, Lars Vinx, Michael Padraic Wolfe and Bill Wringe. Likewise, I am grateful to two anonymous referees for this journal for their helpful comments, criticisms and references. All remaining errors, unclarities or confusions are my own.

\section{BiBLIOGRAPHY}

Antony, L. ed. 2007. Philosophers without Gods. Oxford: Oxford University Press.

Bentham, J. 1843. Anarchical Fallacies. In J. Bowring (ed.), Works, vol. 2.

Berlin, I. 1984. "Two Concepts of Liberty." In Liberalism and its Critics, edited by M. Sandel, 15-36. New York: New York University Press.

Corrado, M. 1996. "Punishment, Quarantine and Preventive Detention." Criminal fustice Ethics 15 (2): 3-13.

Cristi, R. 1998. Carl Schmitt and Authoritarian Liberalism: Strong State, Free Economy, Cardiff: University of Wales Press.

Critchley, S. 2006. “Crypto-Schmittianism," in Infinitely Demanding, 113-48. London: Verso. Dawkins, R. 2001. "Religion’s Misguided Missiles," Guardian Saturday September 15.

Dworkin, R. 1984. "Liberalism." In Liberalism and its Critics, edited by M. Sandel, 60-79. New York: New York University Press.

Harris, S. 2005. The End of Faith: Religion, Terror and the Future of Reason. New York, NY: W.W. Norton. 
Hart, H.L.A. 1963. "Prolegomenon to the Principles of Punishment." In Punishment and Responsibility, edited by H.L.A. Hart, 1-27. Oxford: Clarendon Press.

Heidegger, M. 1933. "Letter to Carl Schmitt, August 1933." In "Heidegger and Schmitt: The Bottom Line," Telos (June 20, 1987): 132; doi: 10.3817/0687072132

—. 1981. "Nur noch ein Gott kann uns retten," Der Spiegel 30 (Mai, 1976): 193-219. Trans. by W. Richardson as "Only a God Can Save Us" in Heidegger: The Man and the Thinker, edited by T. Sheehan, 45-67. Chicago: Precedent Publishing.

Hitchens, C. 2007. God is Not Great: How Religion Poisons Everything. New York, NY: Twelve. Jefferson, T. 1782. Notes on the State of Virginia, edited with an introduction by William Peden, 1955. Chapel Hill, NC: University of North Carolina Press.

Kymlicka, W. 1999. Contemporary Political Philosophy: An Introduction. Oxford: Oxford University Press.

Marder, Michael. 2014. "The Question of Political Existence: Hegel, Heidegger, Schmitt." In Heidegger on Hegel's Philosophy of Right. The 1934-5 Seminar and Interpretative Essays, edited by Peter Trawny, Marcia Sá Cavalcante Schuback, and Michael Marder, 37-48. London: Bloomsbury.

Mensch, J.R. 2017. "Violence and Existence: An Examination of Carl Schmitt's Philosophy." Continental Philosophy Review 50: 249-268.

Miner, R.C. 2012. "Nietzsche, Schmitt, and Heidegger in the Anti-Liberalism of Leo Strauss." Telos: Critical Theory of the Contemporary (160): 9-27.

Rawls, J. 1971. A Theory of Justice. Cambridge: Harvard Belknap Press.

Schmitt, C. 1985. The Crisis of Parliamentary Democracy. Cambridge, MIT Press.

- 2007. The Concept of the Political: Expanded Edition, translated with an introduction by George Schwab, with a Forward by Tracy B. Strong and Notes by Leo Strauss. Chicago, University of Chicago Press.

Selgelid, M.J. 2009. "Infectious Disease." In A Companion to Bioethics, 2nd Ed., edited by H. Kuhse and P. Singer, 430-440. Oxford: Blackwell.

Sherman, P.W., Jarvis, J.U.M., and Alexander, R.D. 1991. The Biology of the Naked Mole Rat. Princeton, NJ: Princeton University Press.

Shermer, M. 2007. "Rational Atheism." Scientific American (September 2007): 44-5.

Strong, T.B. 2007. "Forward: Dimensions of the New Debate around Carl Schmitt." In Schmitt, C. (2007), The Concept of the Political: Expanded Edition, translated with an Introduction by George Schwab, with a Forward by Tracy B. Strong and Notes by Leo Strauss. Chicago, University of Chicago Press.

United Nations Universal Declaration of Human Rights, 1948. In Making Sense of Human Rights, edited by J. Nickel (1987): 191-7.

Walzer, M. 2006. Fust and Unjust Wars, 4th Ed., New York: Basic Books.

Wilkinson, M. 2019. “Authoritarian Liberalism as Authoritarian Constitutionalism.” In Authoritarian Constitutionalism, edited by H. Alviar and G. Frankenberg, 317-37. Cheltenham, UK: Edward Elgar Publishing. 